\title{
Human immunodeficiency virus and mortality from coronavirus disease 2019: A systematic review and meta-analysis
}

\begin{tabular}{|c|c|}
\hline \multicolumn{2}{|c|}{ 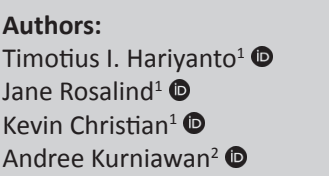 } \\
\hline \multicolumn{2}{|c|}{$\begin{array}{l}\text { Affiliations: } \\
{ }^{1} \text { Faculty of Medicine, } \\
\text { Pelita Harapan University, } \\
\text { Tangerang, Indonesia }\end{array}$} \\
\hline \multicolumn{2}{|c|}{$\begin{array}{l}{ }^{2} \text { Department of Internal } \\
\text { Medicine, Faculty of } \\
\text { Medicine, Pelita Harapan } \\
\text { University, Tangerang, } \\
\text { Indonesia }\end{array}$} \\
\hline \multicolumn{2}{|c|}{$\begin{array}{l}\text { Corresponding author: } \\
\text { Andree Kurniawan, } \\
\text { andree.kurniawan@uph.edu }\end{array}$} \\
\hline $\begin{array}{l}\text { Dates: } \\
\text { Received: } 26 \\
\text { Accepted: } 08 \\
\text { Published: } 15\end{array}$ & $\begin{array}{l}\text { an. } 2021 \\
\text { Mar. } 2021 \\
\text { Apr. } 2021\end{array}$ \\
\hline \multicolumn{2}{|c|}{$\begin{array}{l}\text { How to cite this article: } \\
\text { Hariyanto TI, Rosalind J, } \\
\text { Christian K, Kurniawan A. } \\
\text { Human immunodeficiency } \\
\text { virus and mortality from } \\
\text { coronavirus disease } 2019 \text { : } \\
\text { A systematic review and } \\
\text { meta-analysis. S Afr J HIV } \\
\text { Med. 2021;22(1), a1220. } \\
\text { https://doi.org/10.4102/ } \\
\text { sajhivmed.v22i1.1220 }\end{array}$} \\
\hline \multicolumn{2}{|c|}{$\begin{array}{l}\text { Copyright: } \\
\text { (C) 2021. The Authors. } \\
\text { Licensee: AOSIS. This v } \\
\text { is licensed under the } \\
\text { Creative Commons } \\
\text { Attribution License. }\end{array}$} \\
\hline \multicolumn{2}{|l|}{ Read online: } \\
\hline 品的品 & $\begin{array}{l}\text { Scan this QR } \\
\text { code with your } \\
\text { smart phone or } \\
\text { mobile device } \\
\text { to read online. }\end{array}$ \\
\hline
\end{tabular}

Background: Persons living with human immunodeficiency virus (PLWH) constitute a vulnerable population in view of their impaired immune status. At this time, the full interaction between HIV and severe acute respiratory syndrome coronavirus 2 (SARS-CoV-2) has been incompletely described.

Objective: The purpose of this study was to explore the impact of HIV and SARS-CoV-2 coinfection on mortality.

Method: We systematically searched PubMed and the Europe PMC databases up to 19 January 2021, using specific keywords related to our aims. All published articles on coronavirus disease 2019 (COVID-19) and HIV were retrieved. The quality of the studies was evaluated using the Newcastle-Ottawa Scale for observational studies. Statistical analysis was performed with Review Manager version 5.4 and Comprehensive MetaAnalysis version 3 software.

Results: A total of 28 studies including 18255040 COVID-19 patients were assessed in this meta-analysis. Overall, HIV was associated with a higher mortality from COVID-19 on random-effects modelling fodds ratio $[\mathrm{OR}]=1.19$ [95\% confidence interval $(\mathrm{CI})=1.01-1.39$ ], $\left.p=0.03 ; I^{2}=72 \%\right\}$. Meta-regression confirmed that this association was not influenced by age $(p=0.208)$, CD4 cell count $(p=0.353)$ or the presence of antiretroviral therapy (ART) ( $p=0.647)$. Further subgroup analysis indicated that the association was only statistically significant in studies from Africa $(\mathrm{OR}=1.13, p=0.004)$ and the United States $(\mathrm{OR}=1.30, p=0.006)$.

Conclusion: Whilst all persons ought to receive a SARS-CoV-2 vaccine, PLWH should be prioritised to minimise the risk of death because of COVID-19. The presence of HIV should be regarded as an important risk factor for future risk stratification of COVID-19.

Keywords: coronavirus disease 2019; COVID-19; SARS-CoV-2; HIV; AIDS.

\section{Introduction}

At the end of December 2019, the first cases of a newly discovered acute respiratory illness named coronavirus disease 2019 (COVID-19) were reported in Wuhan, China. ${ }^{1}$ By January 2021, $>88.3$ million infections and 1.9 million deaths worldwide had been reported. ${ }^{2}$ The COVID-19 disease has various clinical manifestations, ranging from mild symptoms such as fever, cough and anosmia to life-threatening conditions including shock, respiratory failure, arrhythmia, overwhelming sepsis and neurological impairment. ${ }^{3,4}$ Meta-analyses have identified several comorbidities, $5,6,7,8,9$ medicines ${ }^{10,11}$ and abnormal laboratory test results ${ }^{12,13}$ associated with a poor outcome. Persons living with human immunodeficiency virus (PLWH) are an at-risk population in view of their impaired immunity. This impairment increases susceptibility to tuberculosis, opportunistic infections and cancer. ${ }^{14}$ In 2019, an estimated 38 million people globally were living with HIV; 1.7 million new (incident) infections and 690000 deaths were reported that year. ${ }^{15}$ Human immunodeficiency virus-infected individuals with immune suppression (impaired T-cell and humoral responses), unsuppressed HIV RNA viral load (untreated or with treatment failure) and comorbid disease (diabetes mellitus, cardiovascular and renal impairment) may be at risk of the life-threatening forms of severe acute respiratory syndrome coronavirus 2 (SARS-CoV-2) infection. ${ }^{16}$ However, this hypothesis requires additional evidence. Results from observational studies have been conflicting. ${ }^{17,18,19,20}$ This meta-analysis aims to explore the impact of HIV and SARS-CoV-2 co-infection on the mortality outcomes of COVID-19 based on available observational studies. 


\section{Research methods and design Eligibility criteria}

This is a systematic review and meta-analysis of published observational studies. Articles were selected if they fulfilled the following entry criteria: compliance with the PICO framework, namely $\mathrm{P}=$ confirmed positive COVID-19 patients, $\mathrm{I}=$ patients living with $\mathrm{HIV}, \mathrm{C}=\mathrm{HIV}$-uninfected persons and $\mathrm{O}=$ mortality in COVID-19-confirmed patients not attributable to unrelated conditions such as trauma. The studies included were randomised clinical trials, cohort, case-cohort and crossover design, and the full-text paper had to be available and to have been published. Excluded studies included non-original research such as review articles, letters or commentaries; case reports; studies in a language other than English; studies of children and youths $<18$ years of age and pregnant women.

\section{Search strategy and study selection}

A systematic search of PubMed and Europe PMC provided many papers. Additional articles were located by analysing the papers cited by the authors of the identified studies. The search terms included ' $\mathrm{HIV}^{\prime}$ or 'human immunodeficiency virus' or 'immunocompromised' or 'immune-deficient' or 'AIDS' or 'acquired immunodeficiency syndrome' and 'SARSCoV-2' or 'coronavirus disease 2019' or 'COVID-19' or 'novel coronavirus' or ' $\mathrm{nCoV}$ '. The selected time-range included 01 December 2019 to 19 January 2021. Only English-language articles were evaluated. Details of the search strategy are listed in Table 1. Studies of HIV and SARS-CoV-2 co-infection with a valid definition of 'mortality' were included. The search strategy is presented in the preferred reporting items for systematic reviews and meta-analyses (PRISMA) diagram.

The initial investigation located 10733 studies. After the removal of duplicates, 8653 records remained. A further 8585 studies were excluded after screening of the titles and abstracts failed to match with the inclusion and exclusion criteria. Of the 68 full-text articles evaluated for eligibility,

\section{TABLE 1: Literature search strategy.}

\begin{tabular}{|c|c|c|}
\hline Database & Keywords & No. of results \\
\hline PubMed & 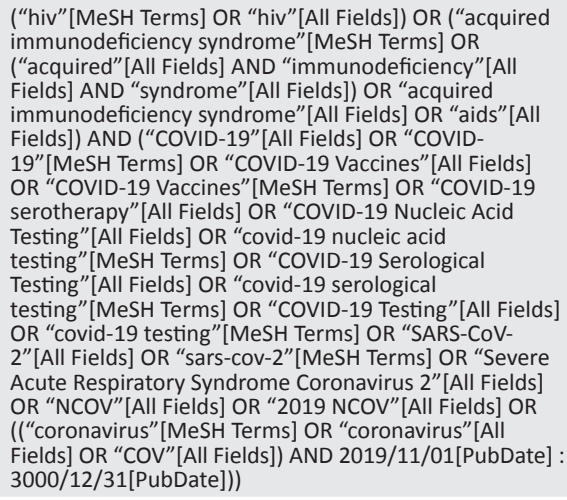 & 1626 \\
\hline $\begin{array}{l}\text { Europe } \\
\text { PMC }\end{array}$ & $\begin{array}{l}\text { "HIV" OR "human immunodeficiency virus" OR } \\
\text { "immunocompromised" OR "immunodeficient" OR } \\
\text { "AIDS" OR "acquired immunodeficiency syndrome" AND } \\
\text { "SARS-CoV-2" OR "coronavirus disease 2019" OR } \\
\text { "COVID-19" }\end{array}$ & 9107 \\
\hline
\end{tabular}

22 that lacked control or comparator groups were excluded, and 15 more were excluded because they lacked outcomes pertinent to our study. Three articles that were not in the English language were rejected. The final meta-analysis included 28 observational studies ${ }^{21,22,23,24,25,26,27,28,29,30,31,32,33,34,35,36,3}$ $7,38,39,40,41,42,43,44$ that reported on 18255040 COVID-19-infected persons, of whom 48703 were co-infected with both HIV and SARS-CoV-2 (see Figure 1). Of the included articles, 25 were retrospective and 3 were prospective (see Table 2 ).

\section{Data extraction and quality assessment}

The study's outcome of interest was mortality from COVID-19. This was defined as the number of patients with COVID-19 whose death could not be attributed to a cause other than COVID-19. Two authors performed the data extraction. Relevant demographic, laboratory and clinical information was recorded on a dataform: age, gender, ethnicity, the number of PLWH, the number of patients with a CD4 cell count of $<200$ cells $/ \mu \mathrm{L}$, the use of antiretroviral therapy (ART) and the mortality outcomes of both HIV-infected and HIVuninfected participants. Two authors independently assessed the quality of each study using the Newcastle-Ottawa Scale. ${ }^{45}$ The selection, comparability and outcome of each study were assigned a score from zero to nine. Studies with scores of $\geq 7$ were considered to be of good quality (see Table 3). All included studies were rated 'good'. In summary, all studies were deemed fit to be included in the meta-analysis.

\section{Statistical analysis}

Review Manager version 5.4 (Cochrane Collaboration) and the Comprehensive Meta-Analysis version 3 software were used in the meta-analysis, and Mantel-Haenszel's formula gave odds ratios (ORs) and 95\% confidence intervals (CIs). The heterogeneity was assessed using the $I^{2}$ statistic with values of $<25 \%, 26 \%-50 \%$ and $>50 \%$ providing low, moderate and high degrees of heterogeneity, respectively. Significance was obtained if the two-tailed $P$-value was $\leq 0.05$.

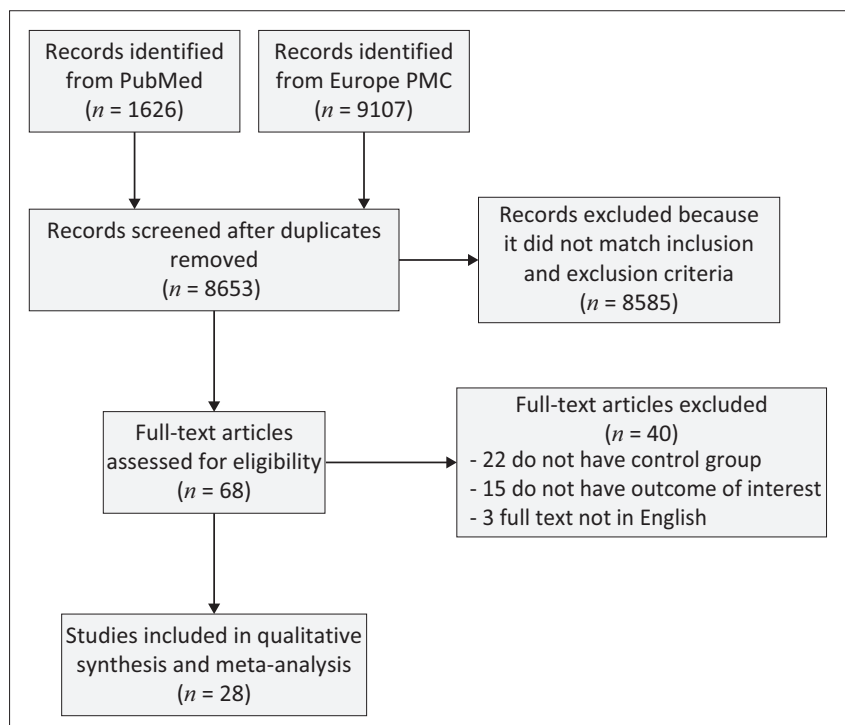

FIGURE1: PRISMA diagram of the detailed process of selection of studies for inclusion in the systematic review and meta-analysis. 
TABLE 2: Characteristics of the included studies.

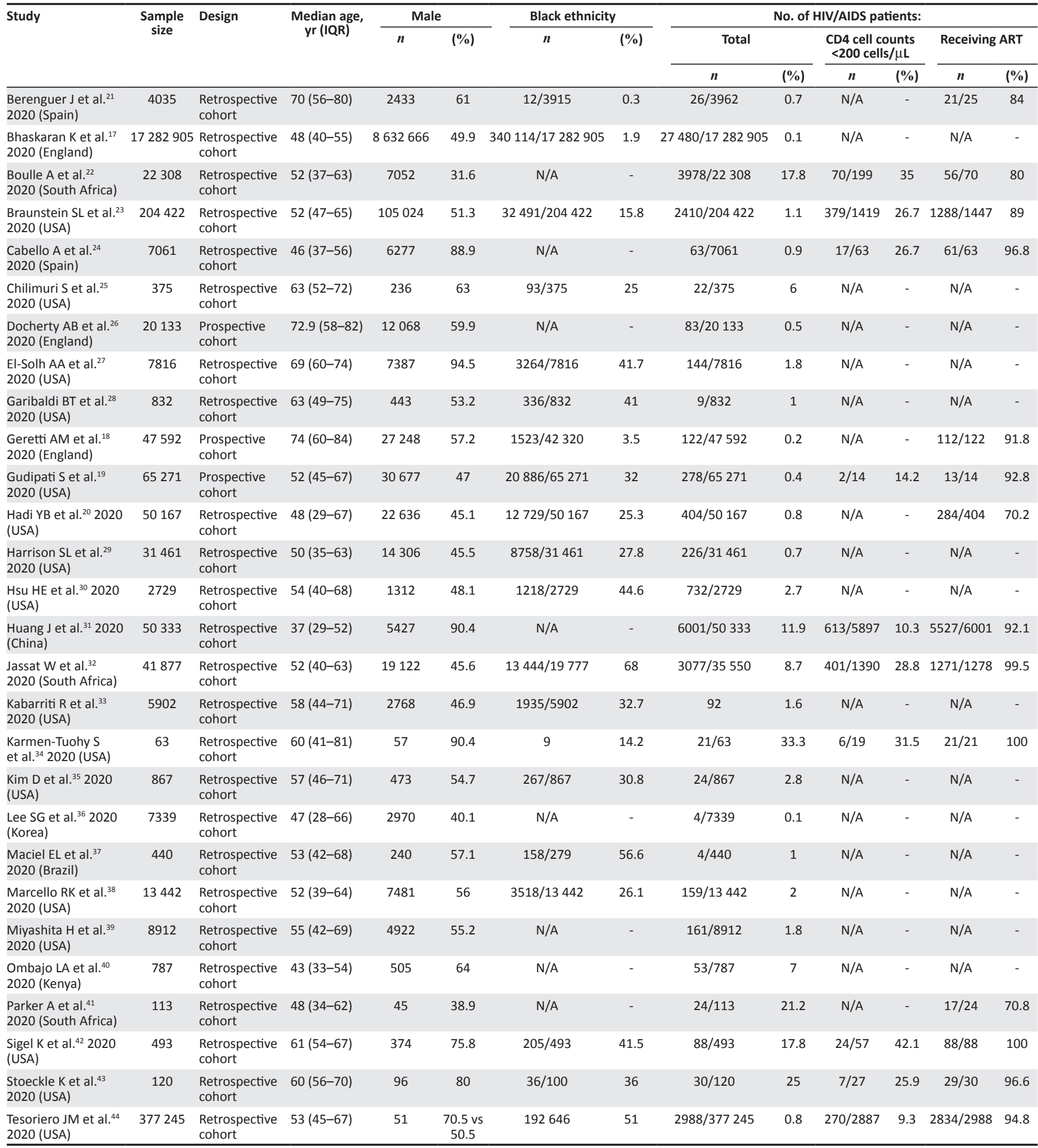

USA, United States of America; ART, antiretroviral therapy; HIV/AIDS, human immunodeficiency virus / acquired immunodeficiency syndrome; IQR, interquartile range; N/A, not applicable.

The qualitative risk of publication bias was assessed using Begg's funnel plot analysis.

\section{Results}

\section{HIV and mortality}

Our pooled analysis indicated that HIV was associated with mortality from COVID-19 [OR $=1.19(95 \% \mathrm{CI}$
1.01-1.39), $p=0.03 ; I^{2}=72 \%$, random-effect modelling] (see Figure 2).

\section{Meta-regression}

However, meta-regression showed that the association between HIV and mortality from COVID-19 was unaffected by age $(p=0.208)$, gender $(p=0.608)$ (see Figure 3a), Black 
TABLE 3: Newcastle-Ottawa quality assessment of observational studies.

\begin{tabular}{|c|c|c|c|c|c|c|c|}
\hline First author & year & Study design & Selection & Comparability & Outcome & Total score & Result \\
\hline Berenguer J et al. ${ }^{21}$ & 2020 & Cohort & $* * *$ & $* *$ & $* * *$ & 8 & Good \\
\hline Bhaskaran K et al. ${ }^{17}$ & 2020 & Cohort & $* * * *$ & $* *$ & $* * *$ & 9 & Good \\
\hline Boulle A et al. ${ }^{22}$ & 2020 & Cohort & $* * *$ & $* *$ & $* * *$ & 8 & Good \\
\hline Braunstein SL et al. ${ }^{23}$ & 2020 & Cohort & $* * *$ & $* *$ & $* * *$ & 8 & Good \\
\hline Cabello A et al. ${ }^{24}$ & 2020 & Cohort & $* * *$ & $* *$ & $* * *$ & 8 & Good \\
\hline Chilimuri S et al. ${ }^{25}$ & 2020 & Cohort & $* * *$ & $* *$ & $* * *$ & 8 & Good \\
\hline Docherty $A B$ et al. ${ }^{26}$ & 2020 & Cohort & $* * * *$ & $* *$ & $* * *$ & 9 & Good \\
\hline El-Solh AA et al. ${ }^{27}$ & 2020 & Cohort & $* * *$ & $* *$ & $* * *$ & 8 & Good \\
\hline Garibaldi BT et al. ${ }^{28}$ & 2020 & Cohort & $* * * *$ & $* *$ & $* * *$ & 9 & Good \\
\hline Geretti AM et al. ${ }^{18}$ & 2020 & Cohort & $* * *$ & $* *$ & $* * *$ & 8 & Good \\
\hline Gudipati S et al. ${ }^{19}$ & 2020 & Cohort & $* *$ & $* *$ & $* * *$ & 7 & Good \\
\hline Hadi YB et al. ${ }^{20}$ & 2020 & Cohort & $* *$ & $* *$ & $* * *$ & 7 & Good \\
\hline Harrison SL et al. ${ }^{29}$ & 2020 & Cohort & $* * *$ & $* *$ & $* * *$ & 8 & Good \\
\hline Hsu HE et al. ${ }^{30}$ & 2020 & Cohort & $* *$ & $* *$ & $* * *$ & 7 & Good \\
\hline Huang J et al. ${ }^{31}$ & 2020 & Cohort & $* * *$ & $* *$ & $* * *$ & 8 & Good \\
\hline Jassat W et al. ${ }^{32}$ & 2020 & Cohort & $* * *$ & $* *$ & $* * *$ & 8 & Good \\
\hline Kabarriti R et al. ${ }^{33}$ & 2020 & Cohort & $* * *$ & $* *$ & $* * *$ & 8 & Good \\
\hline Karmen-Tuohy S et al. ${ }^{34}$ & 2020 & Cohort & $* *$ & $* *$ & $* * *$ & 7 & Good \\
\hline Kim D et al. ${ }^{35}$ & 2020 & Cohort & $* * *$ & $* *$ & $* * * *$ & 9 & Good \\
\hline Lee SG et al. ${ }^{36}$ & 2020 & Cohort & $* * *$ & $* *$ & $* * *$ & 8 & Good \\
\hline Maciel EL et al. ${ }^{37}$ & 2020 & Cohort & $* *$ & $* *$ & $* * *$ & 7 & Good \\
\hline Marcello RK et al..$^{38}$ & 2020 & Cohort & $* * *$ & $* *$ & $* * *$ & 8 & Good \\
\hline Miyashita $\mathrm{H}$ et al..$^{39}$ & 2020 & Cohort & $* *$ & $* *$ & $* * *$ & 7 & Good \\
\hline Ombajo LA et al. ${ }^{40}$ & 2020 & Cohort & $* * *$ & $* *$ & $* * *$ & 8 & Good \\
\hline Parker A et al. ${ }^{41}$ & 2020 & Cohort & $* * *$ & $* *$ & $* * *$ & 8 & Good \\
\hline Sigel K et al. ${ }^{42}$ & 2020 & Cohort & $* * *$ & $* *$ & $* * *$ & 8 & Good \\
\hline Stoeckle K et al. ${ }^{43}$ & 2020 & Cohort & $* * *$ & $* *$ & $* * *$ & 8 & Good \\
\hline Tesoriero JM et al. ${ }^{44}$ & 2020 & Cohort & $* *$ & $* *$ & $* * *$ & 7 & Good \\
\hline
\end{tabular}

Note: Asterisk denotes scores.

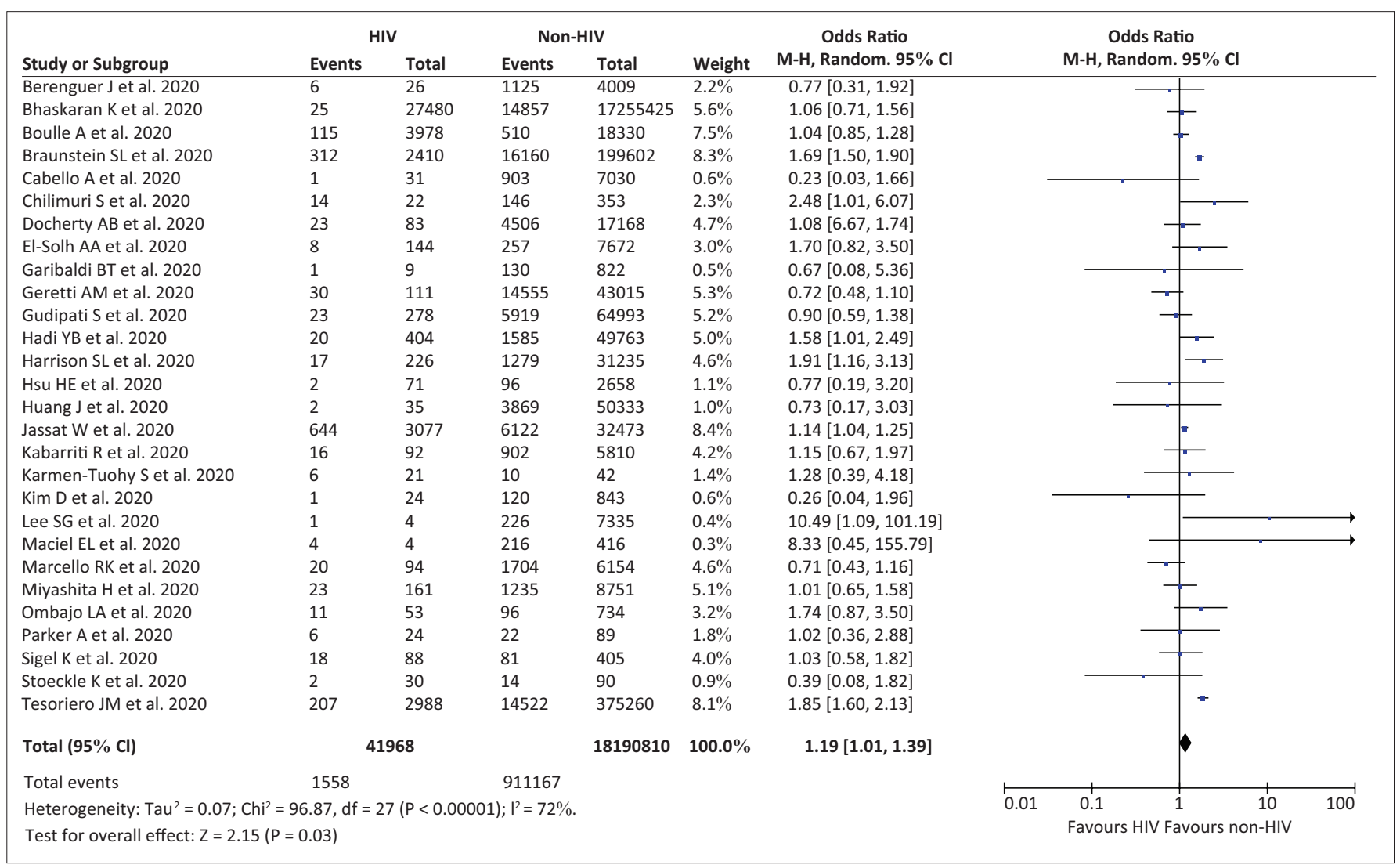

HIV, human immunodeficiency virus; M-H, Mantel-Haenszel; Cl, confidence interval.

FIGURE 2: Forest plot that demonstrates the association of HIV with mortality from COVID-19 outcome. 
ethnicity $(p=0.389)$, CD4 cell count of $<200$ cells $/ \mu \mathrm{L}$ $(p=0.353)$ (see Figure 3b) or ART $(p=0.647)$ (see Figure 3c).

\section{Subgroup analysis}

The subgroup analysis revealed that the association between HIV and mortality from COVID-19 was only statistically significant for studies from African regions $\left[\mathrm{OR}=1.13(95 \% \mathrm{CI}=1.04-1.23), p=0.004 ; I^{2}=0 \%\right.$, randomeffect modelling] and the United States of America (USA) $\left[\mathrm{OR}=1.30(95 \% \mathrm{CI}=1.08-1.59), p=0.006 ; I^{2}=61 \%\right]$ but not for studies from Asia $[\mathrm{OR}=2.41(95 \% \mathrm{CI}=0.16-36.57)$,
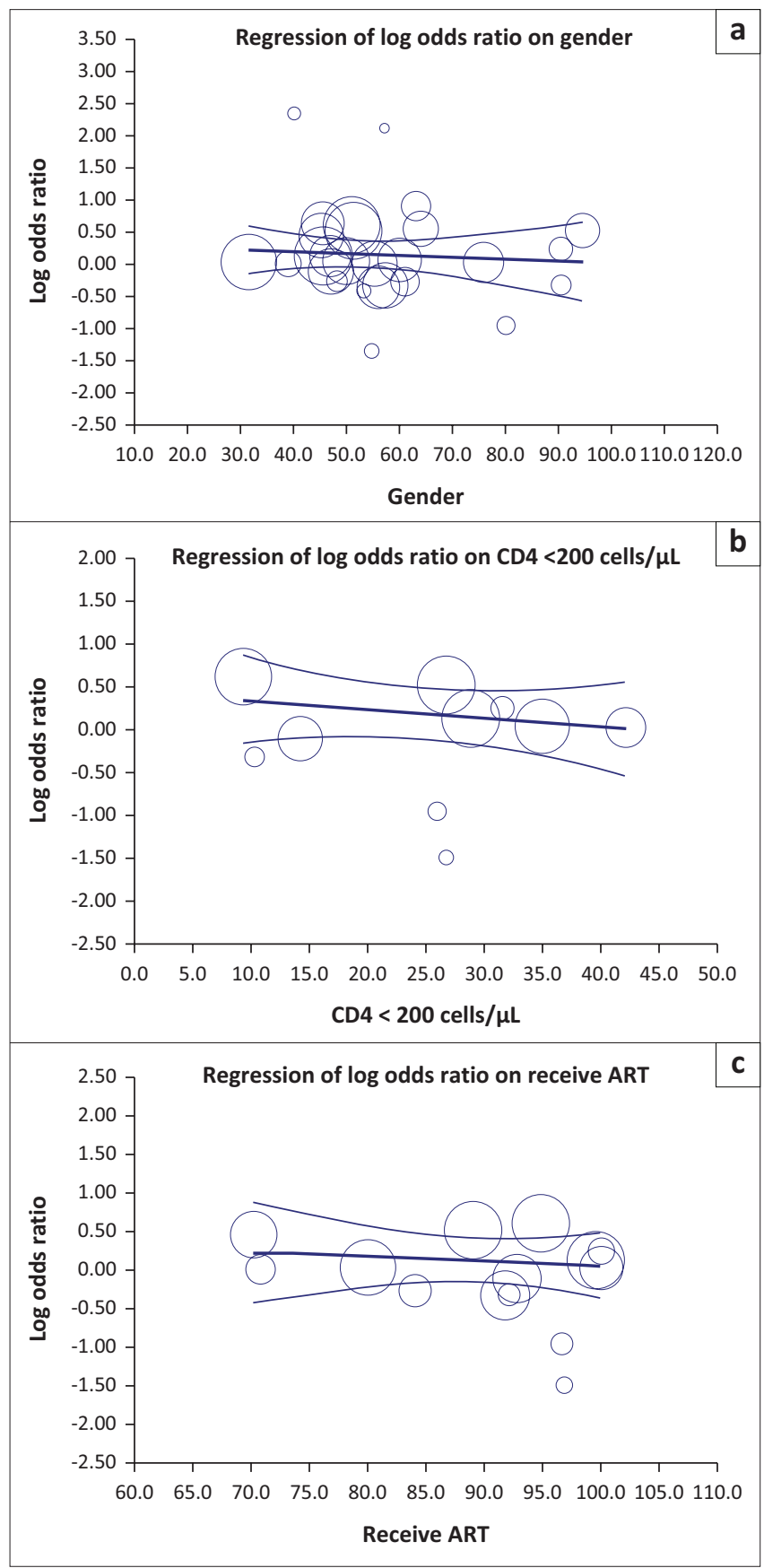

HIV, human immunodeficiency virus; COVID-19, coronavirus disease 2019; ART, antiretroviral therapy.

FIGURE 3: Bubble-plot for meta-regression. Meta-regression analysis showed that the association between HIV and mortality from COVID-19 was not affected by gender (a), CD4 cell count (b) or ART (c). $\left.p=0.53 ; I^{2}=76 \%\right]$, or Europe $[\mathrm{OR}=0.90(95 \% \mathrm{CI}=0.70$ 1.15), $\left.p=0.40 ; I^{2}=5 \%\right]$.

\section{Publication bias}

The funnel plot analysis revealed a qualitatively symmetrically inverted funnel plot for the association between HIV and a mortality outcome, suggesting no publication bias. This is demonstrated in Figure 4.

\section{Discussion}

This systematic review and meta-analysis of 28 studies not only analyse the association between HIV and mortality from COVID-19 but evaluate the role of confounding factors such as age, gender, ethnicity, CD4 cell count and ART in this cohort.

An association was found between HIV and mortality from COVID-19. However, this did not appear to be influenced by the confounding factors above. Instead, the subgroup analysis found that mortality from COVID-19 in PLWH was more likely to be reported in studies from Africa and the USA, rather than Asia or Europe. Factors unique to Africa, such as the large background prevalence of HIV, delayed access to healthcare (poor health 'awareness', an inadequate healthcare infrastructure and logistical challenges to accessing care) and ready access to alternate, non-Western, traditional health practitioners and medicines, are likely to have influenced outcomes. ${ }^{46,47}$ Similarly, the COVID-19 epidemic in the USA disproportionately affected the poor, people of colour and the socially marginalised such as drug users and theinstitutionalised. In both regions, PLWH may have been 'over-represented' in published studies.

Our pooled data confirmed an association of higher mortality from COVID-19 in PLWH

Firstly, HIV infection may cause severe depletion of the gutassociated lymphoid tissue, with a predominant loss of memory CD4+ T cells. ${ }^{48}$ Human immunodeficiency virusinduced T-cell lymphopenia, which disrupts the innate and

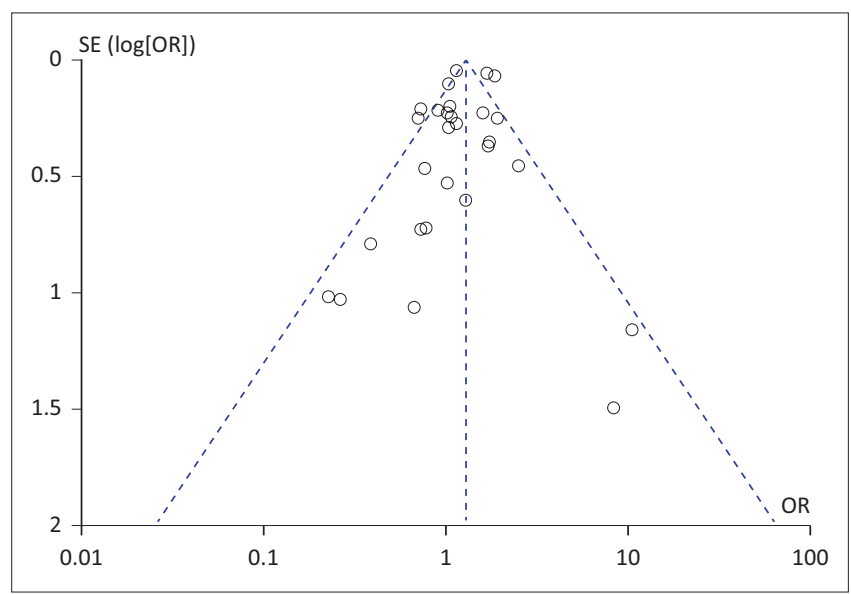

$\mathrm{OR}$, odds ratio; SE, standard error; HIV, human immunodeficiency virus; COVID-19, coronavirus disease 2019.

FIGURE 4: Funnel plot for the association of HIV with mortality from COVID-19 outcomes. 
adaptive immune response, may predispose patients to Mycobacterium tuberculosis infection and progression to active disease, which increases the risk of latent tuberculosis reactivation by 20 -fold. ${ }^{49,50}$ Previously published studies regarding COVID-19 have revealed that the presence of tuberculosis was associated with higher severity and mortality from COVID-19.51,52 Secondly, some proportions of PLWH may have incomplete immune reconstitution and evidence of persistent immune activation. ${ }^{53}$ They may show an abnormal innate and adaptive immune response, characterised by the elevation of macrophages, cytokines [tumour necrosis factor alpha, interleukin (IL)-1, IL-6, IL-8 and IL-10], acute phase proteins [serum amyloid A, C-reactive protein $(\mathrm{CRP})]$, elements of the coagulation cascade (D-dimer and tissue factor), increased turnover and exhaustion of $\mathrm{T}$ cells, increased turnover of $\mathrm{B}$ cells and hyperimmunoglobulinaemia. ${ }^{54,55}$ These conditions may contribute to the development of cytokine storms and severe outcomes in COVID-19. Furthermore, elevated CRP, D-dimer and IL-6 have been associated with severe COVID-19 based on meta-analysis studies. ${ }^{13,56}$ Thirdly, exhaustion of T-cell lymphocytes, which is observed in HIV progression, may also be exacerbated during COVID-19 infection, possibly as a result of the SARS-Cov-2 infection's synergistic activity with HIV, which gradually results in T-cell lymphocyte apoptosis. ${ }^{57}$ This exhaustion of T-cell lymphocytes was associated with the progression and severe manifestation of COVID-19. ${ }^{58,59}$

\section{Limitations}

Firstly, only a limited number of our included studies reported on CD4 cell counts, viral loads and ART - a fact that is likely to have impacted the precision of the meta-regression analysis of this study. Indeed, most studies focussed on the characteristics of COVID-19 patients rather than its effects on PLWH. Secondly, the studies utilised in this review and metaanalysis were primarily observational and thus, may reflect occult confounders or biases unique to the particular study. Finally, we included some preprint studies to minimise the risk of publication bias; however, we made exhaustive efforts to ensure that only sound studies were included that we expect will eventually be published. We hope that this study can give further insight into the management of COVID-19 patients.

\section{Conclusion}

Our meta-analysis of observational studies indicates that HIV had an association with a mortality outcome from COVID-19; however, larger observational studies or even randomised clinical trials are needed to confirm our results and elucidate additional associations. Patients living with HIV must take extra precautions and always adhere to health-promoting protocols. They must be prioritised to receive COVID-19 preventive therapy: the SARS-CoV-2 vaccine. Where feasible, practical use must be made of telemedicine and virtual-based practice to provide continuous care to PLWH throughout this pandemic. Every effort must be made to identify co-infected PLWH and to link them with clinicians and treatment centres skilled in COVID-19 care. Gaps in ART-related care, such as medicine stockouts, must be identified by local healthcare providers and authorities. Finally, HIV co-infection must be included in future risk stratification models for COVID-19 management.

\section{Acknowledgements Competing interests}

The authors declare that they have no financial or personal relationships that may have inappropriately influenced them in writing this article.

\section{Authors' contributions}

T.I.H., J.R., K.C. and A.K. formulated the research questions; T.I.H. and J.R. developed the study protocol, analysed the data and wrote the manuscript. T.I.H., J.R., K.C. and A.K. did the systematic review. A.K. supported and supervised the work. All authors reviewed the manuscript and approved the final version.

\section{Ethical considerations}

This article followed all ethical standards for research without direct contact with human or animal subjects.

\section{Funding information}

This research received no specific grant from any funding agency in the public, commercial or not-for-profit sectors.

\section{Data availability}

The data analysed in this study were a reanalysis of existing data, which are openly available at the locations cited in the reference section.

\section{Disclaimer}

The views and opinions expressed in this article are those of the authors and do not necessarily reflect the official policy or position of any affiliated agency of the authors.

\section{References}

1. Cheng ZJ, Shan J. 2019 Novel coronavirus: Where we are and what we know. Infection. 2020;48(2):155-163. https://doi.org/10.1007/s15010-020-01401-y

2. World Health Organization. Coronavirus disease (COVID-19): Situation report [homepage on the Internet]. [cited 2021 Jan 19]. Available from: https://www. [homepage on the Internet]. [cited 2021 Jan 19]. Available from: https://www.
who.int/publications/m/item/weekly-epidemiological-update---12-january-2021

3. Hariyanto TI, Rizki NA, Kurniawan A. Anosmia/hyposmia is a good predictor of coronavirus disease 2019 (COVID-19) infection: A meta-analysis. Int Arch Otorhinolaryngol. 2021;25(1):e170-e174. https://doi.org/10.1055/s-0040-1719120

4. Hariyanto TI, Kristine E, Jillian Hardi C, Kurniawan A. Efficacy of lopinavir/ritonavir compared with standard care for treatment of coronavirus disease 2019 (COVID-19): A systematic review. Infect Disord Drug Targets. 2020. https://doi.org /10.2174/1871526520666201029125725

5. Hariyanto TI, Kurniawan A. Anemia is associated with severe coronavirus disease 2019 (COVID-19) infection. TransfusApher Sci. 2020;59(6):102926. https://doi. org/10.1016/j.transci.2020.102926

6. Hariyanto TI, Kurniawan A. Thyroid disease is associated with severe coronavirus disease 2019 (COVID-19) infection. Diabetes MetabSyndr. 2020;14(5):1429-1430. https://doi.org/10.1016/j.dsx.2020.07.044

7. Hariyanto TI, Putri C, Arisa J, Situmeang RFV, Kurniawan A. Dementia and outcomes from coronavirus disease 2019 (COVID-19) pneumonia: A systematic review and meta-analysis. Arch GerontolGeriatr. 2020;93:104299. https://doi.org/10.1016/j. archger.2020.104299 
8. Hariyanto $\mathrm{TI}$, Putri C, Situmeang RFV, Kurniawan A. Dementia is a predictor for mortality outcome from coronavirus disease 2019 (COVID-19) infection. Eur Arch Psychiatry Clin Neurosci. 2020;271:393-395. https://doi.org/10.1007/s00406-020Psychiatry

9. Hariyanto $\mathrm{TI}$, Putri C, Situmeang RFV, Kurniawan A. Dementia is associated with severe coronavirus disease 2019 (COVID-19) infection. Am J Med Sci. 2020;361(3):394-395. https://doi.org/10.1016/j.amjms.2020.10.026

10. Hariyanto TI, Prasetya IB, Kurniawan A. Proton pump inhibitor use is associated with increased risk of severity and mortality from coronavirus disease 2019 (COVID-19) infection. Dig Liver Dis. 2020;52(12):1410-1412. https://doi. org/10.1016/j.dld.2020.10.001

11. Hariyanto TI, Kurniawan A. Statin therapy did not improve the in-hospital outcome of coronavirus disease 2019 (COVID-19) infection. Diabetes MetabSyndr. 2020;14(6):1613-1615. https://doi.org/10.1016/j.dsx.2020.08.023

12. Soraya GV, Ulhaq ZS. Crucial laboratory parameters in COVID-19 diagnosis and prognosis: An updated meta-analysis. Med Clin (Engl Ed). 2020;155(4):143-151. https://doi.org/10.1016/j.medcle.2020.05.004

13. Hariyanto TI, Japar KV, Kwenandar F, et al. Inflammatory and hematologic markers as predictors of severe outcomes in COVID-19 infection: A systematic review and meta-analysis. Am J Emerg Med. 2021;41:110-119. https://doi.org/10.1016/j ajem.2020.12.076

14. Chang CC, Crane M, Zhou J, et al. HIV and co-infections. Immunol Rev. 2013;254(1):114-142. https://doi.org/10.1111/imr.12063

15. The Joint United Nations Programme on HIV/AIDS (UNAIDS). Global HIV \& AIDS statistics - 2020 fact sheet [homepage on the Internet]. [cited 2021 Jan 19]. statistics - 2020 fact sheet [homepage on the Internet]. [cite
Available from: https://www.unaids.org/en/resources/fact-sheet

16. Zhu F, Cao Y, Xu S, Zhou M. Co-infection of SARS-CoV-2 and HIV in a patient in Wuhan city, China. J Med Virol. 2020;92(6):529-530. https://doi.org/10.1002/jmv.25732

17. Bhaskaran K, Rentsch CT, MacKenna B, et al. HIV infection and COVID-19 death: A population-based cohort analysis of UK primary care data and linked national death registrations within the OpenSAFELY platform. Lancet HIV. 2021;8(1):e24e32. https://doi.org/10.1016/S2352-3018(20)30305-2

18. Geretti AM, Stockdale AJ, Kelly SH, et al. Outcomes of COVID-19 related hospitalization among people with HIV in the ISARIC WHO Clinical Characterization Protocol (UK): A prospective observational study. Clin Infect Dis. 2020:ciaa1605. https://doi.org/10.1093/cid/ciaa1605

19. Gudipati S, Brar I, Murray S, McKinnon JE, Yared N, Markowitz N. Descriptive analysis of patients living with HIV affected by COVID-19. J Acquir Immune Defic Syndr. 2020;85(2):123-126. https://doi.org/10.1097/QAl.0000000000002450

20. Hadi YB, Naqvi SFZ, Kupec JT, Sarwari AR. Characteristics and outcomes of COVID-19 in patients with HIV: A multicentre research network study. AIDS 2020;34(13):F3-F8. https://doi.org/10.1097/QAD.0000000000002666

21. Berenguer J, Ryan P, Rodríguez-Baño J, et al. Characteristics and predictors of death among 4035 consecutively hospitalized patients with COVID-19 in Spain. Clin Microbiol Infect. 2020;26(11):1525-1536. https://doi.org/10.1016/j. cmi.2020.07.024

22. Boulle A, Davies MA, Hussey $H$, et al. Risk factors for COVID-19 death in a population cohort study from the Western Cape Province, South Africa. Clin Infect population cohort study from the Western Cape Province,
Dis. 2020:ciaa1198. https://doi.org/10.1093/cid/ciaa1198

23. Braunstein SL, Lazar R, Wahnich A, Daskalakis DC, Blackstock OJ. COVID-19 infection among people with HIV in New York City: A population-level analysis of linked surveillance data. Clin Infect Dis. 2020:ciaa1793. https://doi.org/10.1093/ cid/ciaa1793

24. Cabello A, Zamarro B, Nistal S, et al. COVID-19 in people living with HIV: A multicenter case-series study. Int J Infect Dis. 2021;102:310-315. https://doi. org/10.1016/j.jijid.2020.10.060

25. Chilimuri S, Sun $\mathrm{H}$, Alemam A, et al. Predictors of mortality in adults admitted with COVID-19: Retrospective cohort study from New York city. West J Emerg Med. 2020;21(4):779-784. https://doi.org/10.5811/westjem.2020.6.47919

26. Docherty $A B$, Harrison EM, Green CA, et al. Features of 20133 UK patients in hospital with COVID-19 using the ISARIC WHO Clinical Characterisation Protocol: Prospective observational cohort study. BMJ. 2020;369:m1985. https://doi. org/10.1136/bmj.m1985

27. El-Solh AA, Meduri UG, Lawson Y, Carter M, Mergenhagen KA. Clinical course and outcome of COVID-19 acute respiratory distress syndrome: Data from a nationa repository. medRxiv. 2020. https://doi.org/10.1101/2020.10.16.20214130

28. Garibaldi BT, Fiksel J, Muschelli J, et al. Patient trajectories among persons hospitalized for COVID-19: A cohort study. Ann Intern Med. 2020:M20-3905. https://doi.org/10.7326/M20-3905

29. Harrison SL, Fazio-Eynullayeva E, Lane DA, Underhill P, Lip GYH. Comorbidities associated with mortality in 31,461 adults with COVID-19 in the United States: A
federated electronic medical record analysis. PLOS Med. 2020;17(9):e1003321. https://doi.org/10.1371/journal.pmed.1003321

30. Hsu HE, Ashe EM, Silverstein $M$, et al. Race/ethnicity, underlying medical conditions, homelessness, and hospitalization status of adult patients with MMWR Morb Mortal Wkly Rep. 2020;69(27):864-869. https://doi.org/10.15585/ mmwr.mm6927a3

31. Huang J, Xie N, Hu X, et al. Epidemiological, virological and serological features of COVID-19 cases in people living with HIV in Wuhan City: A population-based cohort study. Clin Infect Dis. 2020:ciaa1186. https://doi.org/10.1093/cid/ciaa1186

32. Jassat W, Cohen C, Masha M, et al. COVID-19 in-hospital mortality in South Africa: The intersection of communicable and non-communicable chronic diseases in a high HIV prevalence setting. medRxiv. 2020. https://doi.org/10.1101/2020.12.21.20248409
33. Kabarriti R, Brodin NP, Maron MI, et al. Association of race and ethnicity with comorbidities and survival among patients with COVID-19 at an Urban Medical Center in New York. JAMA Netw Open. 2020;3(9):e2019795. https://doi. org/10.1001/jamanetworkopen.2020.19795

34. Karmen-Tuohy S, Carlucci PM, Zervou FN, et al. Outcomes among HIV-positive patients hospitalized with COVID-19. J Acquir Immune DeficSyndr. 2020;85(1):610. https://doi.org/10.1097/QAl.0000000000002423

35. Kim D, Adeniji N, Latt N, et al. Predictors of outcomes of COVID-19 in patients with chronic liver disease: US multi-center study. Clin Gastroenterol Hepatol. 2020:S1542-3565(20)31288-X. https://doi.org/10.1016/j.cgh.2020.09.027

36. Lee SG, Park GU, Moon YR, Sung K. Clinical characteristics and risk factors for fatality and severity in patients with coronavirus disease in Korea: A nationwide population-based retrospective study using the Korean Health Insurance Review and Assessment Service (HIRA) database. Int J Environ Res Public Health 2020;17(22):8559. https://doi.org/10.3390/ijerph17228559

37. Maciel EL, Jabor P, Goncalves Júnior E, et al. Factors associated with COVID-19 hospital deaths in Espírito Santo, Brazil, 2020. Epidemiol Serv Saude. 2020;29(4):e2020413. https://doi.org/10.1590/S1679-49742020000400022

38. Marcello RK, Dolle J, Grami S, et al. Characteristics and outcomes of COVID-19 patients in New York City's publichospital system. PLoS One. 2020;15(12):e0243027. patients in New York City's publichospital system.
https://doi.org/10.1371/journal.pone.0243027

39. Miyashita H, Kuno T. Prognosis of coronavirus disease 2019 (COVID-19) in patients with HIV infection in New York City. HIV Med. 2021;22(1):e1-e2. https://doi. org/10.1111/hiv.12920

40. Ombajo LA, Mutono N, Sudi P, et al. Epidemiological and clinical characteristics of COVID-19 patients in Kenya. medRxiv. 2020. https://doi.
org/10.1101/2020.11.09.20228106

41. Parker A, Koegelenberg CFN, Moolla MS, et al. High HIV prevalence in an early cohor of hospital admissions with COVID-19 in Cape Town, South Africa. S Afr Med J. 2020;110(10):982-987. https://doi.org/10.7196/SAMJ.2020.v110i10.15067

42. Sigel K, Swartz T, Golden E, et al. Covid-19 and people with HIV infection: Outcomes for hospitalized patients in New York City. Clin Infect Dis. 2020:ciaa880. https://doi.org/10.1093/cid/ciaa880

43. Stoeckle K, Johnston CD, Jannat-Khah DP, et al. COVID-19 in hospitalized adults with HIV. Open Forum Infect Dis. 2020;7(8):ofaa327. https://doi.org/10.1093/ with HIV. Op
ofid/ofaa327

44. Tesoriero JM, Swain CE, Pierce JL, et al. Elevated COVID-19 outcomes among persons living with diagnosed HIV infection in New York state: Results from a population-level match of HIV, COVID-19, and hospitalization databases. medRxiv [Preprint]. 2020:2020.11.04.20226118. https://doi.org/10.1101/2020.11.04.20226118

45. Margulis AV, Pladevall M, Riera-Guardia N, et al. Quality assessment of observational studies in a drug-safety systematic review, comparison of two tools: The Newcastle-Ottawa Scale and the RTI item bank. Clin Epidemiol. 2014;6: 359-368. https://doi/org/10.2147/CLEP.S66677

46. Ajayi Al, Mudefi E, Yusuf MS, Adeniyi OV, Rala N, Goon DT. Low awareness and use of pre-exposure prophylaxis among adolescents and young adults in high HIV and sexual violence prevalence settings. Medicine. 2019;98(43):e17716. https://doi. org/10.1097/MD.0000000000017716

47. Stannah J, Dale E, Elmes J, et al. HIV testing and engagement with the HIV treatment cascade among men who have sex with men in Africa: A systematic review and meta-analysis. Lancet HIV. 2019;6(11):e769-e787. https://doi. org/10.1016/S2352-3018(19)30239-5

48. Chinen J, Shearer WT. Secondary immunodeficiencies, including HIV infection. J Allergy Clin Immunol. 2010;125(2 Suppl 2):S195-S203. https://doi.org/10.1016/j. jaci.2009.08.040

49. Pawlowski A, Jansson M, Sköld M, Rottenberg ME, Källenius G. Tuberculosis and HIV co-infection. PLoS Pathog. 2012;8(2):e1002464. https://doi.org/10.1371/ journal.ppat.1002464

50. Bruchfeld J, Correia-Neves M, Källenius G. Tuberculosis and HIV coinfection. Cold Spring Harb Perspect Med. 2015;5(7):a017871. https://doi.org/10.1101/ cshperspect.a017871

51. Sy KTL, Haw NJL, Uy J. Previous and active tuberculosis increases risk of death and prolongs recovery in patients with COVID-19. Infect Dis (Lond). 2020;52(12):902907. https://doi.org/10.1080/23744235.2020.1806353

52. Gao Y, Liu M, Chen Y, Shi S, Geng J, Tian J. Association between tuberculosis and COVID-19 severity and mortality: A rapid systematic review and meta-analysis. Med Virol. 2021;93(1):194-196. https://doi.org/10.1002/jmv.26311

53. Paiardini $M$, Müller-Trutwin M. HIV-associated chronic immune activation. Immunol Rev. 2013;254(1):78-101. https://doi.org/10.1111/imr.12079

54. Douek DC. Immune activation, HIV persistence, and the cure. Top Antivir Med. 2013;21(4):128-132.

55. Neuhaus J, Jacobs DR Jr, Baker JV, et al. Markers of inflammation, coagulation, and renal function are elevated in adults with HIV infection. J Infect Dis. 2010;201(12):1788-1795. https://doi.org/10.1086/652749

56. Coomes EA, Haghbayan H. Interleukin-6 in covid-19: A systematic review and meta-analysis. Rev Med Virol. 2020;30(6):1-9. https://doi.org/10.1002/rmv.2141

57. Fenwick $C$, Joo V, Jacquier $P$, et al. T-cell exhaustion in HIV infection. Immunol Rev. 2019;292(1):149-163. https://doi.org/10.1111/imr.12823

58. Diao B, Wang C, Tan Y, et al. Reduction and functional exhaustion of T cells in patients with coronavirus disease 2019 (COVID-19). Front Immunol. 2020;11:827. https://doi.org/10.3389/fimmu.2020.00827

59. Yang PH, Ding YB, Xu Z, et al. Increased circulating level of interleukin- 6 and CD8+ T-cell exhaustion are associated with progression of COVID-19. Infect Dis Poverty. 2020;9(1):161. https://doi.org/10.1186/s40249-020-00780-6 